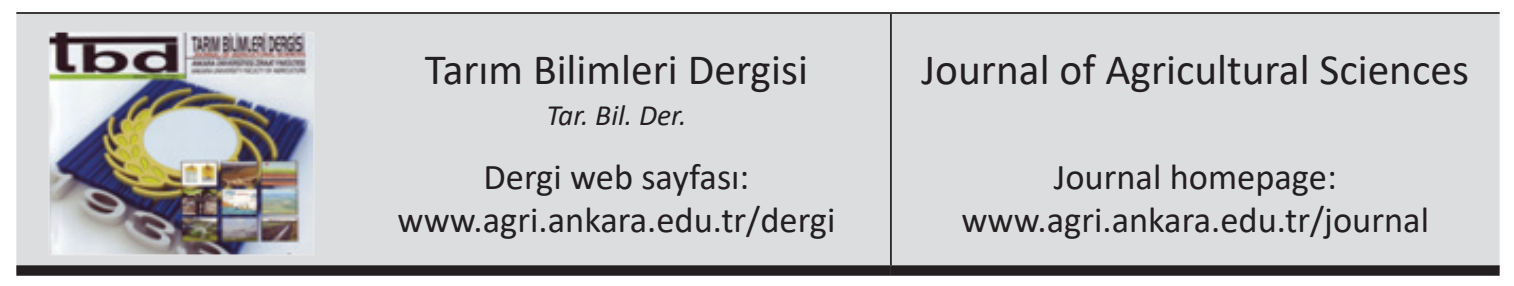

\title{
Barley Leaf Stripe Disease in Algeria: Evaluation of Virulent Pyrenophora graminea Isolates and Identification of Resistant Algerian Barley Genotypes
}

\author{
Hind BENKORTEBY-LYAZIDI ${ }^{\mathrm{a}}$, Imane ZEGHAR ${ }^{\mathrm{b}}$, Leila HANIFI-MEKLICHE ${ }^{\mathrm{c}}$, Zouaoui BOUZNAD \\ ${ }^{a}$ Phytopathology and Molecular Biology Research Laboratory, Botany Department, High National School of Agronomy, Avenue Hassan Badi \\ 16004 El-Harrach, Algiers, ALGERIA

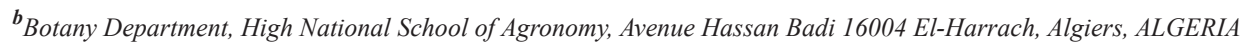 \\ ${ }^{c}$ Control of Water in Agriculture Research Laboratory, Plant Production Department, High National School of Agronomy, Avenue Hassan Badi \\ 16004 El-Harrach, Algiers, ALGERIA
}

\section{ARTICLE INFO}

Research Article

DOI: 10.15832 /ankutbd.421747

Corresponding Author: Hind BENKORTEBY-LYAZIDI, E-mail: hb0recherche@gmail.com, Tel: +213 (550) 374419

Received: 07 May 2018, Received in Revised Form: 24 September 2018, Accepted: 03 October 2018

\begin{abstract}
Nine isolates of Pyrenophora graminea, barley leaf stripe disease causal agent, collected from several regions in Algeria were evaluated under greenhouse conditions for their virulence to a collection of barley cultivars including three most cultivated Algerian varieties. Virulence levels were observed among the set of isolates and a mean disease rate ranging from $3.33 \%$ to $75.83 \%$ was found. Pathogenic variability of $P$. graminea and resistant gene effects in barley cultivars were revealed. Isolate OS was the most virulent among $P$. graminea isolates making it a suitable virulent isolate in future breeding programs. A set of 8 barley genotypes composed of common Algerian cultivars and local developed lines were tested for their reaction to P. graminea and yield response. Barley cultivar Minnesota 23 and line 18/17/7L2 were the most resistant of the collection with high grain number/ear and thousand grains weight even when diseased. These genotypes could be useful to integrate as candidate genitor plants into barley breeding programs to develop resistant cultivars to leaf stripe disease.
\end{abstract}

Keywords: Barley stripe disease; Aggressiveness; Barley; Resistance; Breeding; Algeria

(C) Ankara Üniversitesi Ziraat Fakültesi

\section{Introduction}

Barley (Hordeum vulgare L.) is one of the largest sown crops in the world. In Algeria, barley is a strategic crop and occupies an important place after durum and bread wheat. Thirty five to $40 \%$ of crop areas were reserved for cereals in Algeria (Benmohammed 2004; Rahal-Bouziane 2015; Zairi et al 2016) and a production around 1400 to $2000 \mathrm{~kg} \mathrm{ha}^{-1}$ occurs
(ONFAA 2015). Barley is heavily devastated by barley leaf stripe disease, a widely disseminated seed-born disease caused by the fungal pathogen Pyrenophora graminea (Ito \& Kuribayashi) (anamorph Drechslera graminea ((Rabenh ex. Schlech) Shoemaker). This disease decreases barley yield and quality and induces important economic losses in many countries (Porta-Puglia et al 1986; Arabi et al 2004; Karakaya 
et al 2016). It is the most important barley disease in Algeria. Benbelkacem et al (2000a) evaluated the mean incidence of barley leaf stripe averaging $27.94 \%$, which corresponds to one third of the Algerian potential barley production and estimated an overall yield reduction of $29 \mathrm{~kg}$ per hectare for each $1 \%$ of the disease incidence. Fungicides are effective for reducing the severity of this disease, but the most practical and environmentally sound means of control is through the use of resistant cultivars (Arabi \& Jawhar 2005). Developing resistant cultivars is the best method environmentally and effective one for disease control. However, to breed for resistance to disease, a solid knowledge of the virulence variation information related to pathogen is necessary (Arabi \& Jawhar 2012).

The objective of the present study was to investigate the most aggressive isolate of the $P$. graminea among a collection from different regions of Algeria and to evaluate the reaction and yield response of most cultivated Algerian varieties and local selected lines, under greenhouse conditions to $P$. graminea. The study was also carried out in attempt to develop a breeding program for improving barley local cultivars to leaf stripe disease.

\section{Materials and Methods}

\subsection{Fungal isolates}

Barley leaves showing $P$. graminea stripes, collected from different regions of Algeria, were used to obtain the fungus isolates (Table 1). Infected leaves were cut into pieces and sterilized using 5\% sodium hypochlorite solution $(\mathrm{NaOCl})$ for $5 \mathrm{~min}$ and then washed three times with sterile distilled water. Under sterile conditions and using a binocular loupe, a single spore was removed with a handle and put into Potato Dextrose Agar (PDA) medium. The Petri dishes were left for 7 days of incubation at $21 \pm 1{ }^{\circ} \mathrm{C}$ in the dark. All isolates were derived from single spores cultures.

\subsection{Aggressiveness test}

Nine isolates of $P$. graminea were assessed for their aggressivity on four barley varieties, known for their reaction to $P$. graminea which ranged from susceptible to resistant (Table 1): Rihane 03 (ICARDA), Saïda and Tichedrett (Algeria) and Minnesota 23 (USA). Rihane 03, Saïda and Tichedrett are frequently cultivated in Algeria whereas Minnesota 23 is experimentally used. The inoculum was prepared according to Hammouda (1986) modified sandwich method. Under aseptic conditions, barley seeds were disinfected, following leaf surface sterilization protocol previously described, and put onto a half part of an 8 days old mycelia culture plates, and the other half of the fungal colony was flipped over seeds. Each prepared plate was sealed. For control treatment, seeds were placed between two half of PDA medium without $P$. graminea. The seeds were incubated at $6{ }^{\circ} \mathrm{C}$ for 14 days in the dark. Inoculated and uninoculated seeds were carefully planted into $25 \mathrm{~cm}$ diameter plastic

Table 1- $P$. graminea isolates and barley genotypes used in this study

\begin{tabular}{lllll}
\hline Fungal isolates & Region & Algerian geographic area & Barley genotypes & Origin \\
\hline SST & Sidi taleb/Setif & East & Minnesota 23 & USA \\
BBN & Biskra & South-East & Rihane 03 & ICARDA \\
IP48 & Algiers & North & Saïda & Algeria \\
STF & Setif & East & Tichedrett & Algeria \\
OS & Algiers & North & P11L4 and & Line developed from Algerian \\
MSK & Mascara & North-West & P48/L2 & Populations 48 and $11(*)$ \\
SFOU & Fouara/Setif & East & $18 / 17 / 7 \mathrm{~L} 2$ & Doubled haploid line $(*)$ \\
AD & Aind Defla & South-West & $18 / 3 / 2 \mathrm{BL} 2$ & Genealogical line $(*)$ \\
MBS & Medea & South-West & & \\
\hline
\end{tabular}

(*), developed by Professor Mekliche L. 
pots, at rate of 10 seeds per pots and placed under greenhouse conditions in a randomized complete block design, with three replicates. Infected and uninfected plants were scored at heading stage (GS 50) (Zadoks et al 1974). To estimate infection level, percentage of infected plants was calculated, according to Delogu et al (1989) scale, described as follows: highly resistant $(H R)(0-5 \%$ of infected plants), resistant $(R)(6-11 \%)$, moderately resistant $(M R)(12-26 \%)$, susceptible $(S)(27-78 \%)$ and highly susceptible $(H S)$ (79-100\% of infected plants).

\subsection{Assessment of barley cultivars' reaction to leaf stripe and grain production components}

Eight barley genotypes were used to evaluate their reaction to the most virulent isolate of the nine $P$. graminea isolates collection. These eight genotypes are composed of the four varieties described above and four lines (Table 1) developed by Professor Mekliche L. at our Plant Production Department. Inoculated and control seeds were treated as previously described and then carefully removed from Petri dishes and planted, in greenhouse, directly to cement vats previously filled with soil. In this experiment, randomized complete block design with three replicates was used. Infected and healthy plants were counted at heading stage and infection level was assessed according to Delogu et al (1989) scale as described above. At maturity, plants of each plot were harvested to evaluate grain number per ear $(\mathrm{NG} / \mathrm{E})$ and thousand grain weight (TGW).

\subsection{Computation and data analysis}

Statistical ANOVA and homogeneous groups (Newman-Keuls tests) analyzes were performed to evaluate differences between experienced different factor values.

\section{Results and Discussion}

\subsection{Evaluation of isolates' aggressiveness}

Highly significant virulence levels were observed among five separated homogenous groups (Tables 2 and 3). The mean disease rating was ranged from $3.33 \%$ to $75.83 \%$. Çetin et al (1995) observed infection ranging from $15.4 \%$ to $96.3 \%$. Isolate OS was the most virulent on four cultivars. Therefore, this isolate may be considered as a suitable virulent isolate in the future plantbreeding programs. MBS isolate was found as the least virulent (Table 3 ). Reaction of cultivars to $P$. graminea isolates showed highly significant differences (Tables 2 and 3). The cultivar Minnesota 23 was shown to be resistant to all pathogen isolates with $<5 \%$ of disease reaction. Rihane 03 was resistant to 7 isolates. However, the varieties Saïda and Tichedrett were the most susceptible ones and were resistant to only three isolates. The cultivars Minnesota 23, Rihane 03, Saïda and Tichedrett were suitable for defining virulence because they all provided clear response to the pathogen isolates investigated, whether in aggressiveness test or in barley reactions. They revealed a high level of variability in their reactions. Similar reactions were found by other researchers. Bayraktar \& Akan (2012) also found resistant cultivars with $<20 \%$ of disease reaction. In this study, Minnesota 23 genotype was the most resistant, Rihane 03 was intermediate, Tichedrett and Saïda were susceptible. These results are in agreement with those obtained by Benbelkacem et al (2000b). Analysis of variance showed also highly significant interaction of isolates and cultivars (Table 2) suggesting that cultivars reacted differently to the isolates. Based on those differential reactions between different cultivars and several isolates collected from diverse regions, specific resistance gene effects may exist in the host barley cultivars. Consequently, this indicates the presence of pathogenic variability of $P$. graminea isolates. Variation in pathogenicity of $P$. graminea isolates was mentioned by many researchers (Zriba \& Harrabi 1995; Delogu et al 1995; Benbelkacem et al 2000b; Aminnejad et al 2009; Bayraktar \& Akan 2012; Çelik et al 2016; Karakaya et al 2017). However, groups clustering showed that isolates OS, IP48, MSK and MBS constituted by themselves as statistically different individual groups (Table 3), suggesting that those isolates can be different distinct physiologic races. On the other hand, Algerian East and 
South-West isolates BBN, SFOU, STF, SST, AD (Table1) were gathered into one group (Table 3), with no differential virulence, suggesting that they might be related to the same pathotype. This can be explained by the fact that $P$. graminea is exclusively seed-borne and that Eastern Algerian farmers often supply their needs of barley seeds from the south-western regions and vice versa. The same case happens to South-Western Algerian farmers. Such results were also reported by Benbelkacem et al (2000b).

\subsection{Evaluation of barley cultivars' reaction}

Differences were observed in the reaction of barley cultivars (Table 2) indicating a high level of variability among barley collection for leaf stripe severity. The line 18/3/2BL2 was highly susceptible barley genotype with disease incidence of 90\% followed by Tichedrett (80\%). The genotypes P11L4, P48/L2 and the varieties Saïda and Rihane 03 were susceptible with disease incidence ranging from 50 to $77 \%$. The line $18 / 17 / 7 \mathrm{~L} 2$ was moderately resistant (23\%). The cultivar Minnesota 23 was highly resistant with $3 \%$ disease incidence. Cultivar Minnesota 23 proved to be the most resistant one all through the aggressiveness and the reaction variability tests.

Differences among the reactions of the barley cultivars and lines to the isolates of the barley leaf stripe fungus were also reported by different authors (Ulus \& Karakaya 2007; Bayraktar \& Akan 2012; Çelik et al 2016; Karakaya et al 2017; Çelik Oğuz et al 2017).

Table 2- Mean squares (MS), degrees of freedom (df) and coefficients of variation (CV) from analysis of variance for the studied traits

\begin{tabular}{|c|c|c|c|c|c|c|c|c|}
\hline \multirow{2}{*}{$\begin{array}{l}\text { Studied traits } \\
\text { Sources } \\
\end{array}$} & \multicolumn{2}{|c|}{$\begin{array}{c}\text { Disease rating } \\
\text { aggressivity } \\
(\%)\end{array}$} & \multicolumn{2}{|c|}{$\begin{array}{c}\text { Incidence } \\
\text { (OS isolate inoculation) } \\
(\%)\end{array}$} & \multicolumn{2}{|c|}{ Number of grain/ear } & \multicolumn{2}{|c|}{$\begin{array}{c}\text { 1000-grain weight } \\
\text { (g) }\end{array}$} \\
\hline & $d f$ & $M S$ & $d f$ & $M S$ & $d f$ & $M S$ & $d f$ & $M S$ \\
\hline Cultivars & 3 & $2.538 * * *$ & 7 & $0.235 * * *$ & 7 & $140.952 * * *$ & 7 & $103.356^{* * *}$ \\
\hline Isolates & 9 & $1.386 * * *$ & 1 & $8.626 * * *$ & 1 & $833.333 * * *$ & 1 & $1631.934 * * *$ \\
\hline Varieties isolates & 27 & $0.173 * * *$ & 7 & $0.235 * * *$ & 7 & $27.048 * * *$ & 7 & $166.009 * * *$ \\
\hline Error & 54 & 0.006 & 14 & 0.023 & 14 & 2.610 & 14 & 0.698 \\
\hline $\mathrm{CV}(\%)$ & & 1.639 & & 5.494 & & 8.073 & & 1.741 \\
\hline
\end{tabular}

Table 3- Mean disease aggressiveness rating of $\boldsymbol{P}$. graminea isolates

\begin{tabular}{llllll}
\hline \multirow{2}{*}{ Isolates } & $\begin{array}{l}\text { Mean disease } \\
\text { rating (\%) }\end{array}$ & \multicolumn{4}{c}{ Mean disease rating on barley cultivars (\%) } \\
\cline { 3 - 6 } & & Minnesota23 & Rihane03 & Saida & Tichedrett \\
\hline OS & $75.83 \mathrm{a}^{\mathrm{y}}$ & $10.00 \mathrm{R}$ & $96.67 \mathrm{HS}$ & $96.67 \mathrm{HS}$ & $100.00 \mathrm{HS}$ \\
$\mathrm{IP} 48$ & $49.17 \mathrm{~b}$ & $0.00 \mathrm{HR}$ & $56.67 \mathrm{~S}$ & $83.33 \mathrm{HS}$ & $56.67 \mathrm{~S}$ \\
MSK & $30.83 \mathrm{c}$ & $0.00 \mathrm{HR}$ & $23.33 \mathrm{MR}$ & $66.67 \mathrm{~S}$ & $33.33 \mathrm{~S}$ \\
BBN & $16.67 \mathrm{~d}$ & $3.33 \mathrm{HR}$ & $0.00 \mathrm{HR}$ & $23.33 \mathrm{MR}$ & $40.00 \mathrm{~S}$ \\
SFOU & $14.17 \mathrm{~d}$ & $0.00 \mathrm{HR}$ & $0.00 \mathrm{HR}$ & $26.67 \mathrm{~S}$ & $30.00 \mathrm{~S}$ \\
SST & $14.17 \mathrm{~d}$ & $0.00 \mathrm{HR}$ & $0.00 \mathrm{HR}$ & $36.67 \mathrm{~S}$ & $20.00 \mathrm{MR}$ \\
STF & $14.17 \mathrm{~d}$ & $0.00 \mathrm{HR}$ & $0.00 \mathrm{HR}$ & $26.67 \mathrm{~S}$ & $30.00 \mathrm{~S}$ \\
AD & $10.83 \mathrm{~d}$ & $0.00 \mathrm{HR}$ & $0.00 \mathrm{HR}$ & $23.33 \mathrm{MR}$ & $20.00 \mathrm{MR}$ \\
MBS & $3.33 \mathrm{e}$ & $0.00 \mathrm{HR}$ & $0.00 \mathrm{HR}$ & $13.33 \mathrm{MR}$ & $0.00 \mathrm{HR}$ \\
\hline
\end{tabular}




\subsection{Evaluation of grain number per ear and thousand grains weight components}

Number per ear and thousand grains weight of inoculated barley cultivars was significantly reduced compared to their associated controls and this decrease varied largely between barley genotypes (Table 4). The disease reduced the NG/E of the resistant cultivars Minnesota 23 and 18/17/7L2 by $29 \%$ and $18 \%$. For susceptible cultivars, reduction of $\mathrm{NG} / \mathrm{E}$ ranged between $19 \%$ to $87 \%$. On the other hand, the disease did not affect TGW of the resistant cultivar Minnesota 23 and line 18/17/7L2 while for susceptible genotypes Rihane 03, P11/ L4, Saïda, Tichedrett, P48/L2 and 18/3/2BL2, disease impact reduced TGW of $9 \%, 12 \%, 54 \%$, $56 \%, 80 \%$ and up to $100 \%$ respectively. This study showed that inoculation with $P$. graminea affected grain number per ear and thousand grain weights of diseased cultivars considerably. Arabi et al (2004) reported that the thousand grain weight was affected negatively when barley plants were inoculated with $P$. graminea. However, in our study, the resistant cultivar Minnesota 23 and line 18/17/7L2 showed high number/ear and thousand grain weight while the susceptible ones scored reduced values of these traits. Arabi et al (2001) showed that P. graminea had a direct impact on element storage (as proteins) of susceptible cultivars, whereas no effects were detected in the resistant ones. In our study, the resistance demonstrated in Minnesota 23 and $18 / 17 / 7$ L2 approached closely to those reported in Arabi et al (2001) study. Therefore, it is suggested that cultivar Minnesota 23 and line 18/17/7L2 should be integrated in breeding studies for introducing leaf stripe disease resistance into most cultivated and high yielding varieties.

\section{Conclusions}

The present study showed pathogenic variation among Algerian $P$. graminea isolates and provided insights about reactions of Algerian barley cultivars and resistance sources to barley leaf stripe disease. The agressiveness of the $P$. graminea isolate OS could make it suitable as the virulent isolate in future plant breeding programs. The barley cultivar Minnesota 23 and the line 18/17/7L2 were good sources of resistance and may be useful in developing resistant cutivars. Although our sample size was limited, these prelimenary results indicated presence of good resistance gene effects in Algerian barley cultivars and varieties and diversity in the $P$. graminea pathogen populations of Algeria. For more solid protocols to assist breeding programs, a larger set of isolates collected from different localities should be used and more barley cultivars should be investigated and screened under field conditions.

Table 4- Incidence of $P$. graminea (inoculated with OS isolate) in 8 barley genotypes and its effect on the grain number per ear and 1000-grain weight (g)

\begin{tabular}{|c|c|c|c|c|c|c|c|c|}
\hline \multirow{3}{*}{ Cultivars } & \multicolumn{2}{|c|}{$\begin{array}{c}\text { Barley genotypes } \\
\text { reactions }\end{array}$} & \multicolumn{3}{|c|}{$N G E$} & \multicolumn{3}{|c|}{ 1000-grain weight } \\
\hline & \multirow{2}{*}{$\begin{array}{c}\text { Incidence } \\
(\%)\end{array}$} & \multirow{2}{*}{$\begin{array}{c}\text { Reaction } \\
\text { type }\end{array}$} & \multicolumn{2}{|c|}{ Mean } & \multirow{2}{*}{$\begin{array}{c}\text { Reduction rate } \\
(\%)\end{array}$} & \multicolumn{2}{|c|}{ Mean } & \multirow{2}{*}{$\begin{array}{c}\text { Reduction rate } \\
(\%)\end{array}$} \\
\hline & & & Uni. & Ino. & & Uni. & Ino. & \\
\hline 18/3/2BL2 & $90 \mathrm{a}^{\mathrm{y}}$ & HS & $39.33 \mathrm{~b}$ & $21.00 \mathrm{e}$ & 87 & $52.67 \mathrm{a}$ & $23.00 \mathrm{~h}$ & 129 \\
\hline Tichedrett & $80 \mathrm{a}$ & HS & $29.67 \mathrm{e}$ & $23.00 \mathrm{ge}$ & 29 & $44.67 \mathrm{ef}$ & $28.67 \mathrm{f}$ & 56 \\
\hline P48/L2 & $77 \mathrm{a}$ & $\mathrm{S}$ & $31.67 \mathrm{de}$ & $26.33 \mathrm{efg}$ & 20 & $45.67 \mathrm{de}$ & $25.33 \mathrm{~g}$ & 80 \\
\hline Saïda & $63 \mathrm{ab}$ & $\mathrm{S}$ & $32.67 \mathrm{de}$ & $25.00 \mathrm{fg}$ & 31 & $47.67 \mathrm{bc}$ & $31.04 \mathrm{e}$ & 54 \\
\hline Rihane 03 & $53 \mathrm{ab}$ & $\mathrm{S}$ & $37.67 \mathrm{bc}$ & $31.67 \mathrm{bcd}$ & 19 & $44.67 \mathrm{ef}$ & $41.00 \mathrm{c}$ & 9 \\
\hline P11L4 & $50 \mathrm{ab}$ & $\mathrm{S}$ & $34.67 \mathrm{~cd}$ & $28.33 \mathrm{def}$ & 22 & $39.67 \mathrm{~g}$ & $35.33 \mathrm{~d}$ & 12 \\
\hline 18/17/7L2 & $23 \mathrm{~b}$ & MR & $43.66 \mathrm{a}$ & $37.00 \mathrm{a}$ & 18 & $48.67 \mathrm{~b}$ & $46.67 \mathrm{a}$ & 4 \\
\hline Minnesota23 & $3 \mathrm{c}$ & HR & $42.67 \mathrm{a}$ & $33.00 \mathrm{~b}$ & 29 & $43.67 \mathrm{f}$ & $43.00 \mathrm{~b}$ & 2 \\
\hline
\end{tabular}

y, different letter, means significantly different at $\mathrm{P}<0.05$ (Newman-Keuls test) 


\section{References}

Aminnejad M, Babai-Ahari A, Javan-Nikkhah M \& Saeid Hejazi M (2009). Molecular and pathogenic variation within Iranian Pyrenophora graminea population; more polymorphism in IGS region. AmericanEurasian Journal of Agricultural \& Environmental Sciences 6: 697-704

Arabi M I E \& Jawhar M (2005). Barley reaction to Pyrenophora graminea based on the fungus movement. Australasian Plant Pathology 34: 405-407

Arabi M I E \& Jawhar M (2012). Pathogenic groups identified among isolates of Pyrenophora graminea. Journal of Plant Biology Research 1(2): 93-100

Arabi M I E, Mirali N, Jawhar M \& Al-Safadi B (2001). The effects of barley seeds infected with Pyrenophora graminea on storage proteins (Hordeins) patterns. Plant Variety Seeds 14: 113-117

Arabi M I E, Jawhar M, Al-Safadi B \& Mirali N (2004). Yield responses of barley to leaf stripe (Pyrenophora graminea) under experimental conditions in southern Syria. Journal of Phytopathology 152: 519-523

Bayraktar H \& Akan K (2012). Genetic characterization of Pyrenophora graminea isolates and the reaction of some barley cultivars to leaf stripe disease under greenhouse conditions. Turkish Journal of Agriculture and Forestry 36: 329-339

Benbelkacem A, Boubkeur R \& Boulif M (2000a). Les pertes de rendements causées par la maladie striée (Pyrenophora graminea) de l'orge en Algérie. Al Awamia 101-Juin 2000: 53-65

Benbelkacem A, Boulif M, Amir A \& Ceccarelli S (2000b). Variation in the pathogenicity of 20 Algerian isolates of Pyrenophora graminea Ito \& Kur. on nine barley (Hordeum vulgare L.) varieties. Phytopathologia Mediterranea 39(3): 389-395

Benmohammed A (2004). La production de l'orge et possibilités de développement en Algérie. Céréaliculture 41: 34-38

Çelik Oğuz A, Karakaya A \& Ergün N (2017). Determination of the reactions of some Turkish hulless barley lines to Drechslera graminea. Works of the Faculty of Agriculture and Food Sciences University of Sarajevo Vol. XLII, 67(2): 196-202

Çelik Y, Karakaya A, Çelik Oğuz A, Mert Z, Akan K, Ergün N \& Sayim İ. (2016). Determination of the reactions of some barley landraces and cultivars to Drechslera graminea. Mediterranean Agricultural Sciences 29(2): 43-47

Çetin L, Albustan S, Düsünceli F, Tosun H \& Akar $\mathrm{T}$ (1995). Determination of resistance of barley breeding materials developed for Central Anatolia to barley leaf stripe (Pyrenophora graminea). In VII. Türkiye Fitopatoloji Kongresi, 26-29 Eylül, Adana, Turkey, pp. 126

Delogu G, Porta-Puglia A C \& Vannacci G (1989). Resistance of winter barley varieties subjected to natural inoculums of Pyrenophora graminea. Journal of Genetics and Breeding 43: 61-65

Delogu G, Porta-Puglia A, Stanca A M \& Vannacci G (1995). Interaction between barley and Pyrenophora graminea: an overview of research in Italy. Rachis 14: 29-34

Hammouda A M (1986). A modified technique for inoculation in leaf stripe of barley. Acta Phytopathologica et Entomologica Hungarica 21(34): 255-259

Karakaya A, Mert Z, Çelik Oğuz A \& Çetin L (2016). Distribution of barley stripe disease in Central Anatolia, Turkey. Selcuk Journal of Agriculture and Food Sciences 30(2): 59-61

Karakaya A, Çelik Oğuz A \& Rahimi A (2017). Response of Iranian barley landraces to Drechslera graminea. Works of the Faculty of Agriculture and Food Sciences University of Sarajevo Vol. XLII, 67(2): 225-230

ONFAA (Observatoire National des filières Agricoles et Agroalimentaires) (2015). Bilan de la campagne céréalière 2014/2015. Ministère de l'Agriculture, $d u$ Développement Rural et de la Pêche de l'Algérie Janvier 2015: 7-8

Porta-Puglia A, Delogu G \& Vannacci G (1986). Pyrenophora graminea on winter barley seed: effect on disease incidence and yield losses. Phytopathology 117: 26-33

Rahal-Bouziane H (2015). L'orge en Algérie:passé, présent et importance pour la sécurité alimentaire, face aux nouveaux défis. Recherche Agronomique 27: 7-9

Ulus C \& Karakaya A (2007). Assessment of the seedling reactions of some Turkish barley cultivars to barley stripe. Tarım Bilimleri Dergisi 13(4): 409-412

Zadoks J C, Chang T T \& Konzak C F (1974). A decimal code for the growth stage of cereals. Weed Research 14: 415-421

Zairi M, Bouchentouf S, Hadjam N, Benali M, Hamou M \& Labdi M (2016). La qualité technologique de quelques lignées d'orge issue de la sélection participative en zones semi-arides. Revue Agriculture 1: $162-173$

Zriba W \& Harrabi M (1995). Cultural and pathogenic variability in Pyrenophora graminea isolates. Rachis 14: 99 